2003

\title{
Illustrating Shakespeare
}

Ackerman, Sandra; Baskin, Leonard; Daub, Peggy; Reinhardt, Nancy S.

https://hdl.handle.net/2027.42/120255

https://creativecommons.org/licenses/by/4.0/

Downloaded from Deep Blue, University of Michigan's institutional repository 


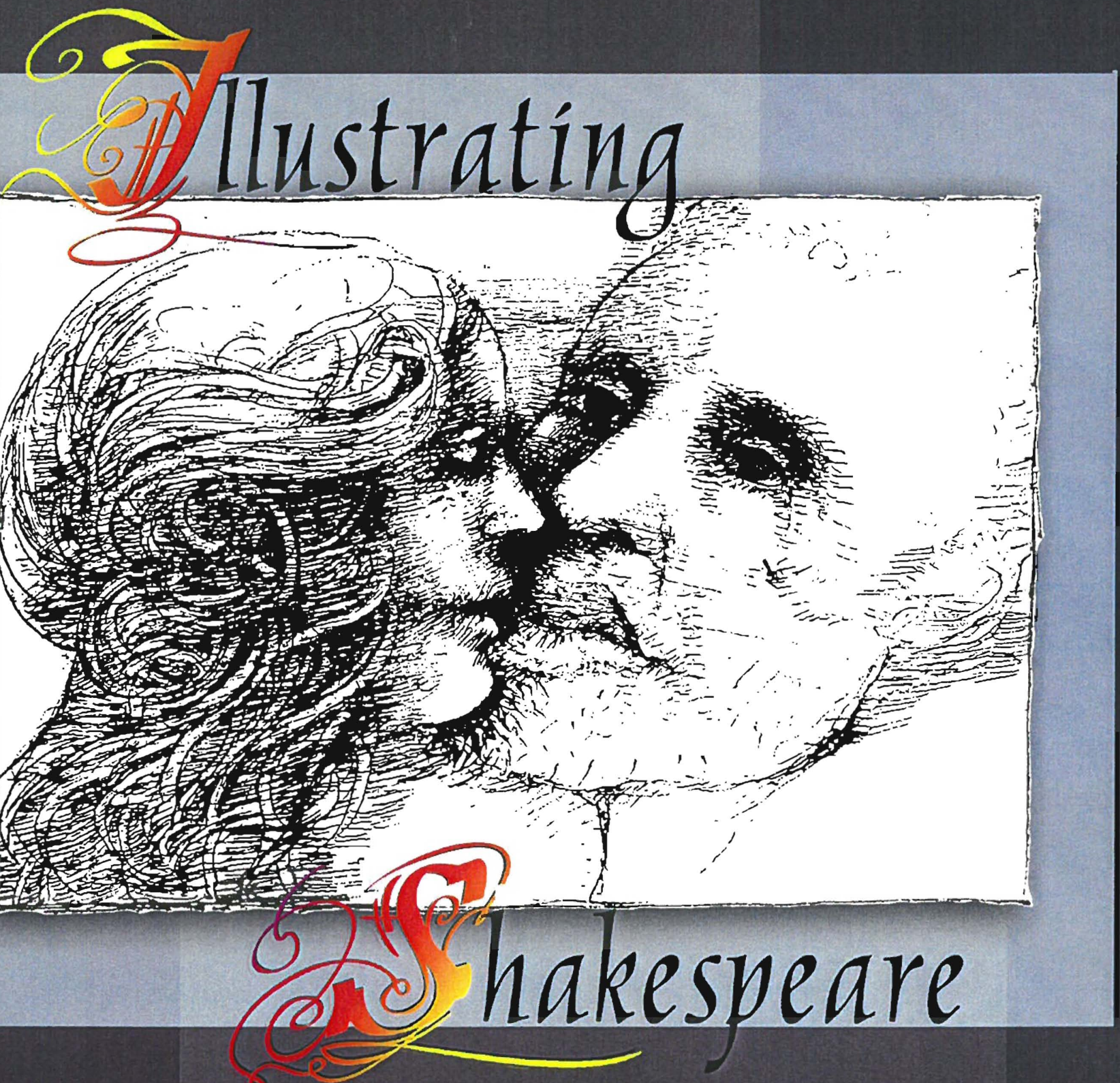




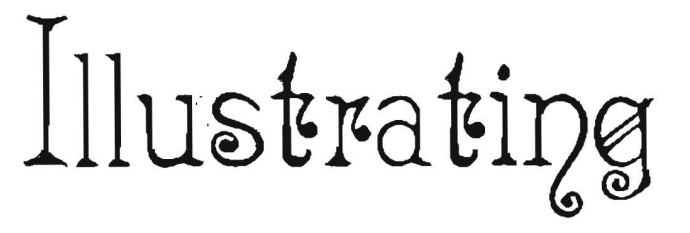

Shakespeare

January 20-March I6, 2003

Special Collections Library University of Michigan Library Ann Arbor, Michigan 
Welcome to this exhibit tracing the course of printed illustrations of Shakespeare's works over the last 300 years. Through this exhibit we are celebrating both the March 2003 return visit of the Royal Shakespeare Company to the University of Michigan and the expansive collection of Shakespearean materials boused in the Special Collections Library.

The McMillan Shakespeare Collection in the University of Michigan Library was founded in the 1880s with some 1200 items acquired from the private collections of two noted Shakespeare collectors: Edward H. Thomson, of Flint, Michigan, and Joseph Crosby, of Zanesville, Ohio Senator James A. McMillan, the collection's namesake, and his family generously provided the funds both for the acquisition of these two initial collections and for further additions made over the next twenty-five years under the direction of University of Michigan English Professor Isaac Demmon.

The McMillan Collection now numbers approximately 6,000 volumes, providing a rich and varied resource for documenting the bistory of how Shakespeare's works were both presented and received. With thousands of different English and American editions ranging from the Second Folio of 1632 to popular editions of the 1910s, as well as scholarly and popular analyses of the works, the collection traces Shakespeare's influence on Anglo-American culture from many different angles. There are also editions in some 20 languages other than English and books and pamphlets about every imaginable aspect of Shakespeare's life and his works, ranging from the debate over who wrote the works said to be by Shakespeare, to the role of such things as music, flowers, and women in bis works.

Saturday Io am - I2 pm

Copyright 2003 by the University of Michigan Library

University of Michigan, Ann Arbor

University of Michigan Board of Regent:

David A. Brandon Rebecca McGowan

Laurence B. Deitch Andrea Fischer Newma

Daniel D. Horning S. Martin Taylor

Olivia P. Maynard Katherine E. Whit

Mary Sue Coleman (ex officio)

Cover design by Sandra Ackerman

Cover Illustration @ Leonard Baskin, used with permission
Shakespeare's rich textures of plot and character are mirrored in the rich variety of images they have inspired. Curator Nancy S. Reinhardt here presents a guided tour through the historical process of printed illustrations, showing how paintings, set and costume design, and actor themselves all influenced that history. The items in the exhibit vividly show bow the vital emotions that Shakespeare's words stirred in a multitude of artists were then translated into illustrations that in turn evoke those same emotions in others.

I would like to thank and recognize Nancy S. Reinhardt, Curator of Theatre, Film, and Television Collections in the Special Collections Library, who served as Curator of this exhibit. She was ably assisted in the exhibit's preparation by the Library's Conservation Staff, including Shannon Zachary, Leyla Lau Lamb, and Thomas Hogarth, and in mounting the exhibit by staff of the Special Collections Library, including Kathleen Dow and Franki Hand. Sandy Ackerman of the Library's Public Relations Office designed the catalogue cover and publicity materials for this exhibit, and Franki Hand of the Special Collections Library laid out the remainder of the catalogue.

Peggy Daub, Head

Special Collections Library 


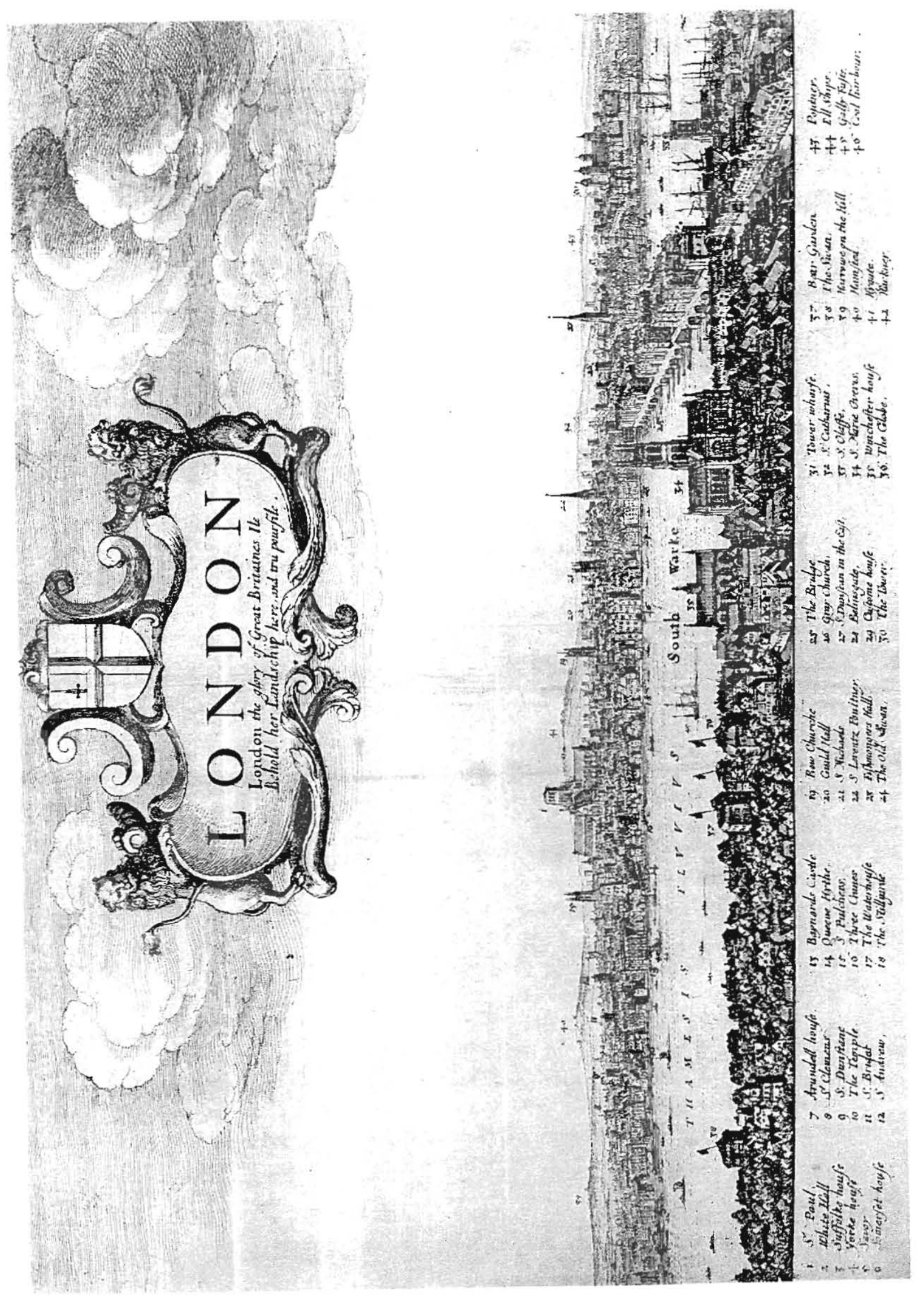

Illustrating Shakespeare ....

There are so many ways of representing the words of the Bard - on and off stage, in paintings, film and television, and of course in a wide variety of illustrated books. The subject is so complex that no exhibit can do full justice to its range and variety. In museums, art galleries and the collections of great libraries there are thousands of images from

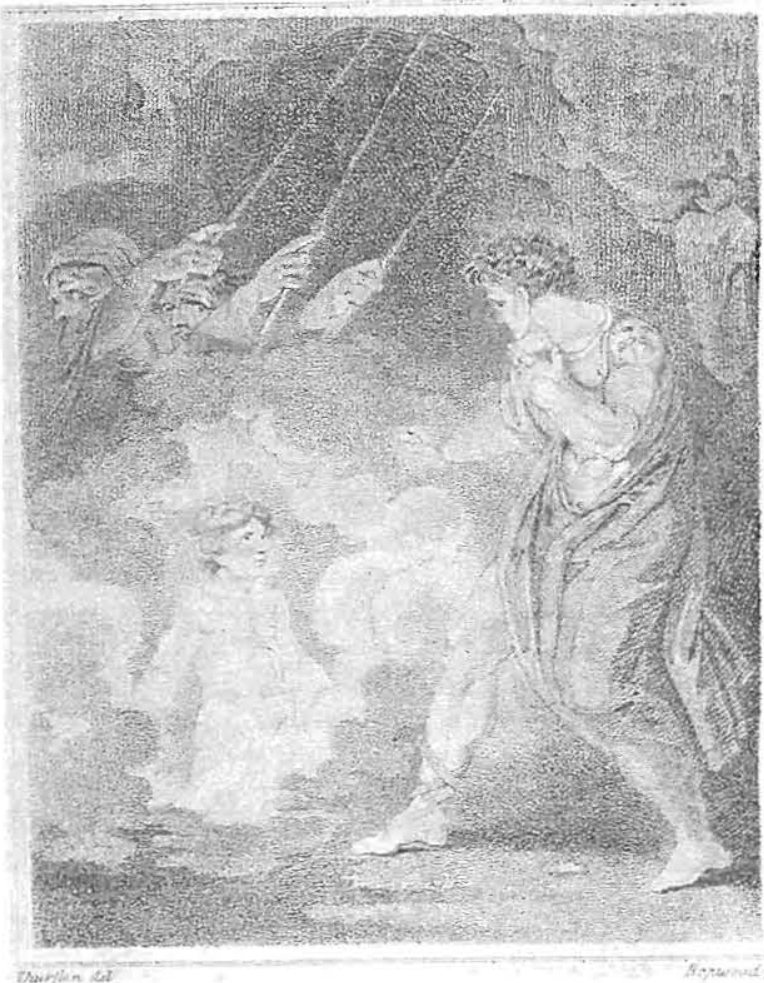

Shakespeare ... paintings, drawings, woodcuts, engravings, lithographs, photographs, even sculptures survive of characters seen on stage or imagined off stage. This exhibit makes no attempt to provide a full display of these complexities. Rather, it celebrates the University Library's rich holdings in Shakespeare. Examples are drawn from the multiple editions of his works, as well as from his predecessors and contemporaries, to trace the emerging tradition of the illustrated text. The different interpretations of Shakespeare's characters shown here provide a context for the modern interpretations of the Royal Shakespeare Company in residence at the University of Michigan in Ann Arbor, in March 2003. 


\section{Self-Guided Tour of the Exhibit ....}

The exhibit is organized in seven clusters of floor cases, with corresponding wall cases offering expanded interpretations of the items in the floor cases. Unless otherwise indicated, all the items in the floor cases are original books or prints from the Specia Collections Library of the University of Michigan Library. While many of the images in the wall cases are copies of pages from the collections, several are original items. Each item is numbered with a brief bibliographical citation, and whenever possible the artist associated with the example is identified. The following outline is a brief guide to the associated with the example is
central themes of each cluster.

I CASES $1,2,3$

II

CASES 4,5

CASES 6, 7

CASES $8,9,10$
Early Book Illustration in England,

Documentary Images from Shakespeare's

World and the First Illustrated Editions of His Plays

Editions of Coriolanus and The Merry Wives of Windsor, with Images of Falstaff. Artists or ditions represented in CASE 4 are from the 18 century, and in CASE 5, from the $19^{\text {th }}$ century.

Ghosts, Fairies, Elves, Visions, Dreams, Nightmares. Artists or editions represented are from the $18^{\text {th }}, 19^{\text {th }}$ and early $20^{\text {th }}$ centuries.

Actors, Interpretations of the Role, and Illustrations of Specific Characters. Most of the books and images in these cases are from the $18^{\text {th }}$ and $19^{\text {th }}$ centuries, the great period of the actor/manager in the English theatre.

Illustrating the "Other" - Orientalism, Dark Alien Figures,Mad Women, etc.

Illustrating Shakespeare's Poetry - the Sonnets, "Who Is Silvia?" and "The Seven Ages of Man.

20th-Century Artists - a Few Examples
Backgrounds to the Exhibit: Early Book Illustration in England, Documentar Images from Shakespeare's World, and the First Illustrated Editions of His Plays

In the first case (CASE 1) early examples of book illustration in England are on display. The oldest book in the exhibit, Expositio Hymnorum, was printed by Richard Pynson in 1497, 67 years before the birth of Shakespeare. Except for a few classics such as Aesop's Fables, chronicles and texts used for religious or political propaganda were more likely to be illustrated than contemporary works of literature. CASE 1 provides several examples of chronicles, a major source for Shakespeare's history plays. Other examples have been selected because the illustrations are by artists associared with Shakespeare (for example, Martin Droeshout who created the portrait for the First Folio, discussed in CASE 3).

In CASE 2, the adjacent wall case, there is an image (reduced in scale by about $50 \%$ ) from a 1964 facsimile of the first illustrated book published in England, William Caxton's The Myrrour of the World (1481). Also on display are two facsimiles representing the earliest known attempts to illustrate Shakespeare, along with an assortment of documentary images from Shakespeare's world. The first known illustration of Shakespeare is a rough drawing in manuscript, not intended for publication - a sketch of an early production of Timon of Athens (ca. 1595). The second is the first published illustration of a work by Shakespeare - an engraved frontispiece illustrating the suicide of Lucrece in The Rape of Lucrece and published in 1655, a full thirty-nine years after Shakespeare's death.

CASE 3 displays the second edition of the First Folio, the first collected edition of Shakespeare's plays, with the famous Martin Droeshout portrait of Shakespeare and Ben Jonson's poem, "To the Reader." CASE 3 also features Hamlet from several of the earliest illustrated editions of the plays. The first illustrated edition (1709) depicts a scene from Hamlet with the famous Restoration actor Thomas Betterton in the title role. The acting ' edition, adapted by Sir William Davenant, for Betterton's Hamlet is also on display.

\section{CASE 1}

1 RANULF HIGDEN, d. 1364

Polycronycon

Southwark, for John Reynes, [1527]

Note the dynamic design by an anonymous artist for this woodcut depicting clashing armies.

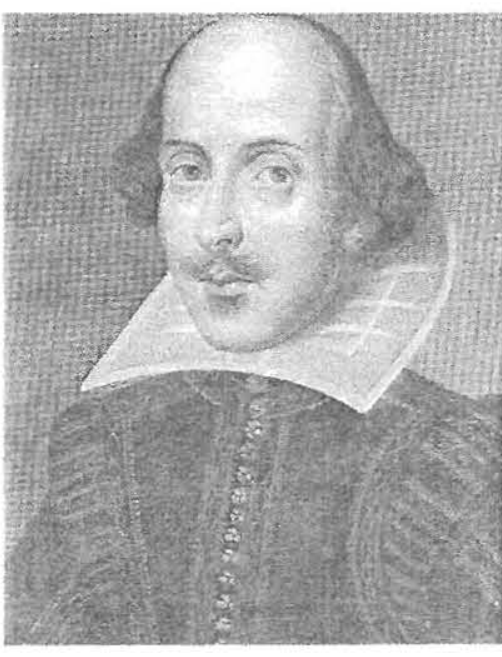


Faithorne, 1616-1691, and foreigner, Wenceslaus Hollar, 1607-1677. Hollar is the same artist who engraved the plates for the costume book, previously owned by Cruikshank, and featured in CASE 5 .

This unsigned woodcut illustrates the defeat in 633 of the Anglians by King Oswald of Northumbria, who had recently converted to Christianity.

3 EXPOSITIO HYMNORUM

London, Richard Pynson, [1497]

This modest book, a school hymnal for choir boys, is the oldest in the exhibit. The opening page is decorated with a simple woodcut that the printer Richard Pynson may have imported from the Continent, as he did for many of his illustrated texts. At the end of the $15^{\text {th }}$ century and well into Shakespeare's time, boys from choir schools often acted in a variety of theatricals. It was probably from among their ranks that some of the first boy actors were selected for women's roles in Shakespeare's plays.

\section{JOHN MILTON, $1608-1674$}

\section{Paradise Lost}

Illustration for Book I by John Baptist Medina

London, for R. Bentley and J. Tonson, 1688

With its subtle chiaroscuro this dramatic engraving marks a turning point in literary book illustration in England.

5 THOMAS CRANMER, 1489-1556

Answer unto a Crafty and Sophistical Cavillation

London, John Day, 1580

This woodcut illustrating the martyrdom of Thomas Cranmer, Archbishop of Canterbury, appeared originally in John Foxe's Book of Martyrs, also printed by John Day (first English version 1563, expanded and revised 1576). These woodcuts, which would have seemed quite horrifying at the time, were useful political propaganda for the Church of England.

\section{SIR HENRY SPELMAN, 1564?-164}

Aspilogia

In: Nicolai Uptoni De Studio Militari ...

Edited by Sir Edward Bysshe, 1615?-1679

Illustration by Pierre Lombart, 1612-1682

London, for J. Martyn and J. Allestrye, 1654

The engravings on display in this folio are part of a two-page visual narrative depicting the life of a knight. The artist was one of many French engravers working in London during the $17^{\text {th }}$ century. This book also includes engravings by a native artist William
7 THOMAS HEYWOOD, d. 1641

Englands Elisabeth, Her Life and Troubles

Frontispiece by Martin Droeshout, b. 1601

Cambridge, for Ph. Waterhouse, 1632

Heywood like Shakespeare worked as a poet, playwright and actor on the English stage. His play of the same title, written almost 30 years earlier, is perhaps the inspiration for this chronicle. During their reigns Queen Elizabeth and her father King Henry VIU were popular subjects for portraits, chronicles and laudatory plays.

8 THOMAS HEYWOOD, d. 1641

The Hierarchie of the Blessed Angells

Illustration by Martin Droeshout, b. 1601

London, Adam Islip, 1635

This book is of particular interest to Shakespeare scholars because of Heywood's use of the Macbeth legend and his reference on p.206 to "mellifluous Shakespeare."

\section{CASE 2 left panel}

1 Woodcut of the Red Cross Knight

From The Fairie Queene by Edmund Spenser, 1552?-1599

London, 1596

Spenser, a contemporary of Shakespeare, was honored during his lifetime by a few illustrations. Poetry was held in higher esteem culturally than plays and among works of literature was more likely to be illustrated than texts for the theatre.

2 Woodcut of Abraham and Isaac

From $A$ Chronicle at Large ... by Richard Grafton, d.1572

London, 1569

Grafton was a prolific editor of early chronicles; this is one of his several publications. 
Woodcut from a facsimile of

The Mirrour of the World

Printed originally by William Caxton in 1481

Now printed by hand at the Allen Press

[Kentfield, Calif.], 1964

Caxton's Myrrour is cited as the first illustrated book in England. His Canterbury Tales is the first illustrated Chaucer, printed in 1484

$4 \quad$ Engraved portrait of Sir Henry Spelman

by William Faithorne, 1616-169

From Aspilogia, in Nicolai Uptoni De Studio Militari ...

London, 1654

Faithorne was a skilled engraver of portraits.

5 Engraved frontispiece to

The Rape of Lucrece by William Shakespeare, 1564-1616

London, 1655

The first known publication of any illustration of Shakespeare's writings, traditionally attributed to William Faithorne. In contrast to the sophisticated portraits known to be by Faithorne, this unsigned design seems unskilled.

6 Sketch of an early production of

Titus Andronicus by William Shakespeare, 1564-1616

Attributed to Henry Peacham, ca.1595

Private collection, England

\section{CASE 2 right panel}

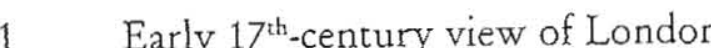

With exterior of Swan Theatre, Globe Theatre ...

From Londinopolis by James Howell, 1594?-1666

London, 1657

2 Sketch of Swan Theatre interior by the Dutch traveler Johannes de Witt, ca. 1596 University Library, Utrecht

3 Close-up of Globe Theatre exterior

From Visscher's View of London, 1606-1614 by Claes Jansz Visscher, 1586/7-1652 British Museum, London

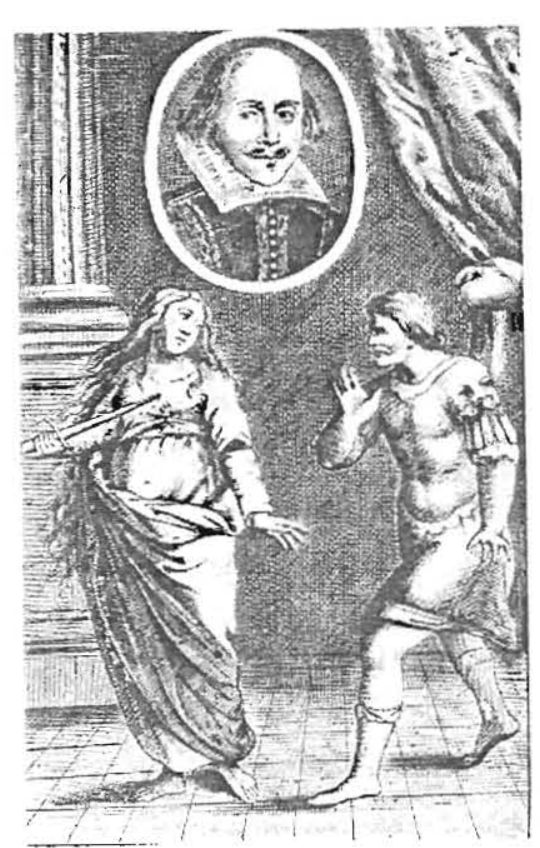

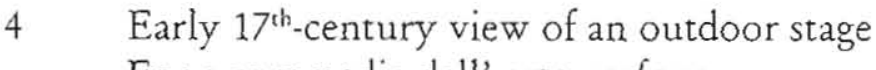

For a commedia dell' arte performance

From Balli di Sfessania

Etching by Jacques Callot, 1592-1635

5 Illustration of a theatre interior, with an image of Falstaff

From the Commonwealth period (?)

Reprinted in Wits or Sport upon Sport

By Francis Kirkman, 1632-ca.1680

London, 1662

6 Woodcut illustration for the title page of

The Roaring Girl by Thomas Middleton, d.1627 and

Thomas Dekker, ca. 1572-1632

London, 1611

$7 \quad$ Engraving by Wenceslaus Hollar, 1607-1677 of a London merchant daughter's costume

From a reprint of the 1643 Theatrum Mulierum...

London, 1790

Previously owned by George Cruikshank

(See original item in CASE 5, no.9)

8 Engraved title page for a costume book

The English Gentlewoman ... by Richard Brathwait, 1588?-1673 London, 1631

\section{CASE 3}

1 WILLIAM SHAKESPEARE, 1564-1616

Mr. William Shakespeares Comedies, Histories, and Tragedies

Second impression

Portrait by Martin Droeshout, b. 1601

London, for Robert Allot, 1632

This is the "Second Folio" or the second impression of the "First Folio" (1623). The title leaf is wanting, supplied in $19^{\text {th }}$-century facsimile. The $17^{\text {th }}$-century green morocco binding, gold-stamped with the arms of the House of Stuart, is also of interest. Facing the title page, note the poem by Ben Jonson (signed "B.I.") praising Shakespeare, whose wit surpasses all artists' attempts to depict his likeness "in Brasse." 
WILITAM SHAKESPEARE, 1564-1616 Hamlet

The Works of Shakespear, in six volumes, v. 6 Edited by Sir Thomas Hanmer, 1677-1746 Illustration by Francis Hayman 1708-1776 Oxford, printed at the Theatre, 1744

This new illustrated edition, in quarto format, show the influence of the fashionable rococo French style.

3 WILLIAM SHAKESPEARE, 1564-1616 The Tragedy of Hamlet, Prince of Denmark Adapted by Sir William Davenant, 1606-1668 Thomas Betterton named in the title role London, for J. Martyn and H. Herringman, 1676

4 WILLIAM SHAKESPEARE, 1564-1616

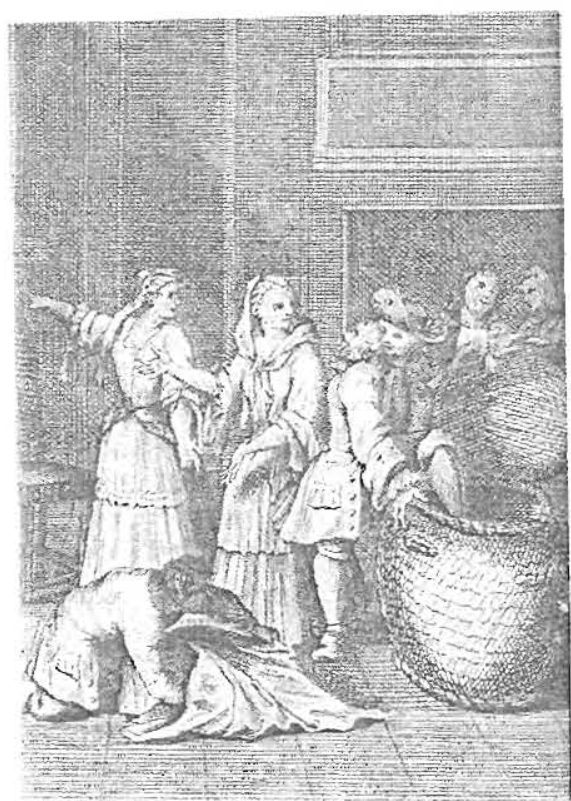

Hamlet

The Works of Mr. William Shakespear, in six volumes, v.5

Edited by Nicholas Rowe, 1674-1718

Cllustration depicting Thomas Betterton as Hamlet

Illustration after François Boitard

London, for Jacob Tonson, 1709

This volume is from the first illustrated edition of Shakespeare's plays. Other examples are on display in CASE 4.

5 WILLIAM SHAKESPEARE, 1564-1616

\section{Hamlet}

The Works of Mr. William Shakespear, in ten volumes, v. 8

Edited by Alexander Pope, 1688-1744

Illustration by Louis Du Guernier, 1677-1716

London, for J. and J. Knapton, 1728

\section{CASES 4 and 5}

Editions of Coriolanus and The Merry Wives of Windsor, with Images of Falstaff. Artists or editions represented in Case 4 are from the $18^{\text {th }}$ century, and in Case 5, from the $19^{\text {th }}$ century.

CASE 4 features $18^{\text {th }}$-century illustrated editions of The Merry Wives of Windsor and Coriolanus, the two Shakespeare plays scheduled for performance during the Royal Shakespeare Company's residency at the University in March 2003. CASE 4 also identifies an important turning point in the history of Shakespearean illustration. During the last decade of the $18^{\text {th }}$ century several series of new paintings based on scenes from Shakespeare's of paintings. This series was so influential that one could say we possess "pre-Boydell" Shakespearean illustrations and "post-Boydell" illustrations.

The idea for the Boydell Gallery was first discussed over dinner in 1786 by John Boydell, a publisher and dealer in prints, his nephew Josiah Boydell, and several leading artists including Benjamin West and George Romney. With capital from his successful business, John Boydell commissioned well over 150 new paintings of scenes from Shakespeare. Thirty-four of these were first exhibited in 1789 in a large gallery on the Pall Mall. Numerous engravings of these scenes were made from the Boydell paintings and several are on display in this exhibit. Because of their size, only one can fit easily in CASE 4 (see Robert Smirke's illustration of Falstaff in The Merry Wives of Windsor), but two other original Boydell engravings based on A Midsummer Night's Dream are mounted on the wall in CASE 7 (two versions of Puck - one by Sir Joshua Reynolds and one by Henry Fuseli)

CASE 5 continues the display of "post Boydell illustrations" of the two featured plays, The Merry Wives of Windsor and Coriolanus. Examples are primarily from $19^{\text {th }}$-century editions, including two from the European Continent. In the $19^{\text {th }}$ century, not only artists from the British Isles but also many from the Continent and North America were enthusiastic about illustrating Shakespeare.

At the right side of CASE 5 is the volume The Life of Sir John Falstaff by Robert Barnabas Brough illustrated by George Cruikshank. Below this book is a 1790 reprint of the 1643 edition of a costume book illustrating the dress of women in England and in several other European countries. The engravings are by Wenceslaus Hollar and right next to a few of Hollar's designs are pencil sketches of Hollar's figures. Inside the front cover, a bibliographer has noted that this copy is from the library of George Cruikshank. It therefore may be assumed that these are Cruikshank's sketches of $17^{\text {th }}$ century costumes based on Hollar's engravings. Some of the costumes represented in Hollar's book are not unlike the costumes Cruikshank etched in his illustrations of scenes from Falstaff's life. Victorians often imagined biographies of characters beyond their written lives. In Brough's Falstaff we have a fully imagined life of a fictional character. Further evidence of the Victorian fascination with "realism" and archeological explorations of legendary settings and characters is the popular Pictorial Edition of the Works of Shakspere, edited by Charles Knight. The Knight edition is replete with "historically accurate" descriptions and wood engravings illustrating the settings for the plays. 


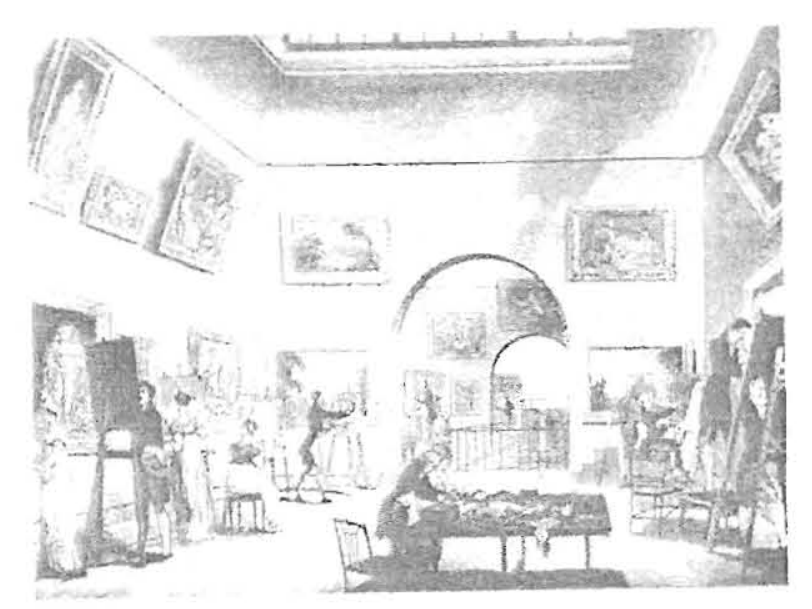

CASE 4

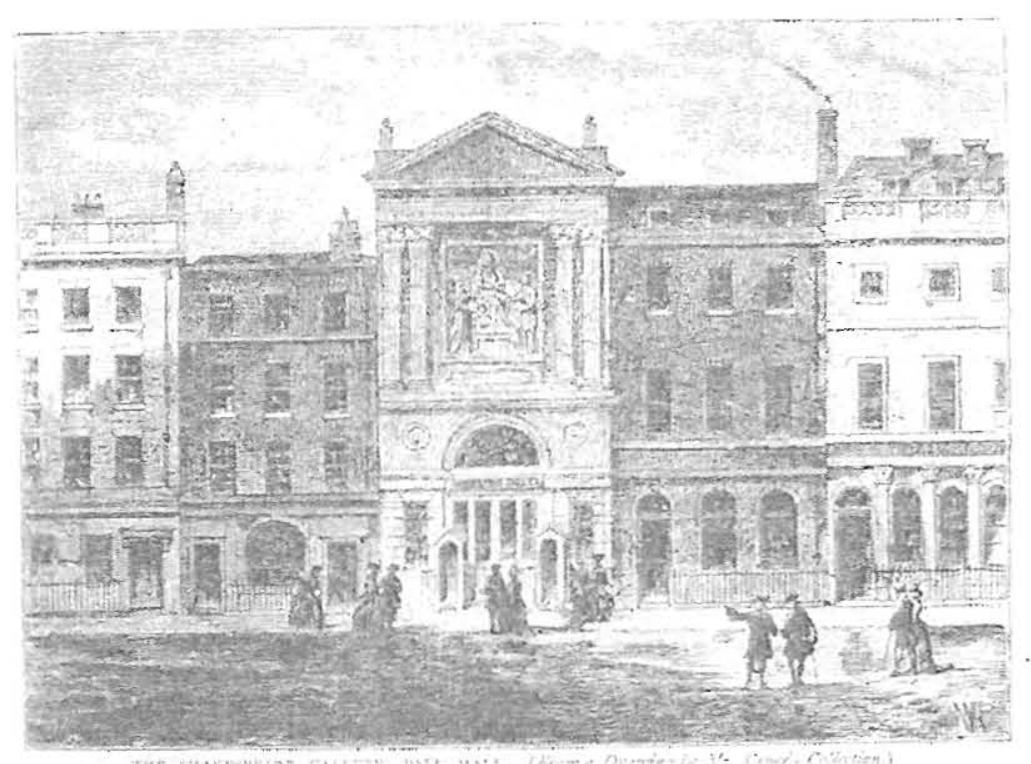

1 WILLIAM SHAKESPEARE, 1564-1616

Coriolanus

The Works of Mr. William Shakespear, in six volumes, v.4

Illustration after François Boitard

London, for Jacob Tonson, 1709

2 WILLIAM SHAKESPEARE, 1564-1616

\section{Coriolanus}

The Works of Mr. William Shakespear, in eight volumes, v. 5

Illustration by Louis Du Guernier, 1677-1716

London, for Jacob Tonson, 1714

3 WILLIAM SHAKESPEARE, 1564-1616

\section{Coriolanus}

The Works of Shakespeare, in eight volumes, v.6

Illustration by Hubert François Gravelot, 1699-1773

London, for H. Lintott, C. Hitch, J. and R Tonson, ..., 1740

4 WILLIAM SHAKESPEARE, 1564-1616

Coriolanus

The Plays of William Shakespeare, v. 5

Illustration by Daniel Dodd, fl. 1760-1790

London, for Bellamy and Robarts, 1791

5 JOHN BOYDELL, 1719-1804

Coriolanus

The Boydell Gallery, a Collection of Engravings Illustrating the Dramatic Works of Shakespeare, by the Artists of Great Britain

Illustration by Gavin Hamilton, 1723-1798

London, Bickers and Son, 1874

6 WILLIAM SHAKESPEARE, 1564-1616 Coriolanus

The Plays of William Shakespeare, in twelve volumes,

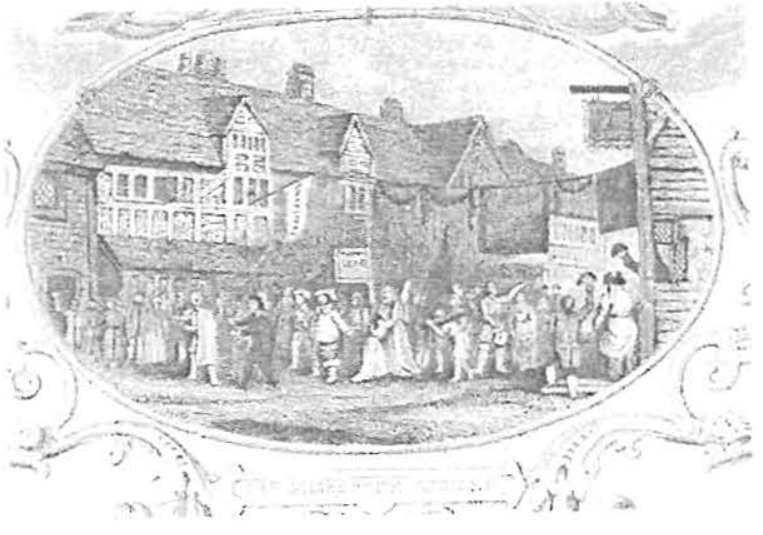

Illustration after Gavin Hamilton, 1723-1798 London, for E. Harding, 1800

7 JOHN BOYDELL, 1719-1804

Falstaff with Buck's Horns

The Merry Wives of Windsor

Shakespeare, Plates from Boydell

Illustration by Robert Smirke, 1752-1845

[London, J. \& J. Boydell, 1791-1803]

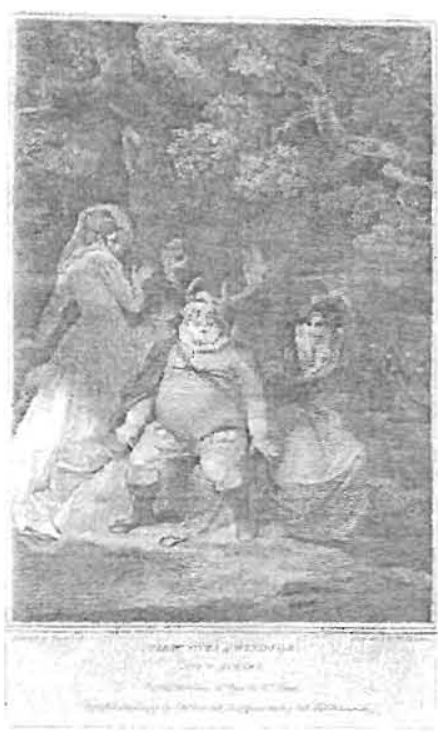


8 JOHN BOYDELL, 1719-1804

A Catalogue of the Pictures. Etc.

in the Shakespeare Gallery, Pall Mall

London, for the proprietors, 1802

This Boydell catalogue is open to the entry (No. LXVI, 1792) for Smirke's original painting of Falstaff (see above no.7).

9 WILLIAM SHAKESPEARE, 1564-1616

The Merry Wives of Windsor

The Plays of William Shakespeare, $\mathrm{v} .2$

Illustration by Henry James Richter, 1772-1857

London, for Bellamy and Robarts, 1791

10 WILLIAM SHAKESPEARE, 1564-1616

The Merry Wives of Windsor

The Plays of William Shakespeare, in twelve volumes, v.10

Illustration by William Nelson Gardiner, 1766-1814

London, for E. Harding, 1800

The publisher, E. Harding, had his shop on the Pall Mall, not far from the Boydell Gallery of Shakespeare paintings. His new illustrated edition is one of many that reflect the influence of Boydell.

\section{CASE 5}

1 WILLIAM SHAKESPEARE, 1564-1616

The Merry Wives of Windsor

The Comedies, Histories, Tragedies, and Poems of Shakspere, v.3

The second edition

London, Charles Knight and Co., 1842-1844

During the mid- and late-19 $9^{\text {th }}$ century, the editor and publisher, Charles Knight, issued ditions of Shakespeare that specialized in archeological research, with hundreds of small wood engravings illustrating the historical background to each of the plays.

\section{AMÉDÉE PICHOT, 1795-1877}

Les Joyeuses femmes de Windsor. The Merry Wives of Windsor

Galérie des Personnages de Shakspeare

Paris, Baudry, Librairie Européenne, 1844

The frontispiece to this section of Pichot's commentary is decorated with what is apparently a pirated version of the design engraved for Knight's 1839-1843 Pictorial Edition. For many decades, Knight's editions of Shakespeare were imitated at home and abroad
3 WILLIAM SHAKESPEARE, $1564-1616$

\section{Coriolanus}

The Pictorial Edition of the Works of Shakspere, $\mathrm{v}$

London, Charles Knight and Co., [1839]-1843

4 EDWARD DOWDEN, 1843-1913

Shakespeare Scenes and Characters

Illustration by Max Adamo, 1837-190

London, Macmillan and Co., 1876

In the $19^{\text {th }}$ century, interest in Shakespeare was widespread. Among the many foreigners illustrating Shakespeare is Max Adamo, the German artist who designed this sensitive portrait of Coriolanus with his family.

5 EDUARD VON GRÜTZNER, 1846-1925

Ed. Grützners Falstaff-Bilder

Berlin, Photographische Gesellschaft, [1893]

6 WILLIAM SHAKESPEARE, 1564-1616

The Library Shakspeare, v.1

Illustration for The Merry Wives of Windsor (III.3) by Robert Dudley, fl. 1858-1893 London, Edinburgh, Glasgow, William Mackenzie, [1873-1875]

7 WILLIAM SHAKESPEARE, $1564-1616$

The Merry Wives of Windsor

The Irving Shakspeare, v. 6

Illustration by Charles Robert Leslie, 1794-1859

London, Henry Irving, 1906

This is a late reproduction of a painting by the quintessentially Victorian painter, Charles Robert Leslie, who places Falstaff in a comfortable contemporary setting, dining with his friends.

8 ROBERT BARNABAS BROUGH, $1828-1860$ The Life of Sir John Falstaff

Illustration by George Cruikshank, 1792-1878

London, Longman, Brown, Green, Longmans, and Roberts, 1858

9 Theatru[m] Mulierum, sive, Varietas atq[ue] Differentia

Illustrations engraved by Wenceslaus Hollar, 1607-1677

London, Laurie \& Whittle, [1790]

According to a bibliographer's entry at the front, this is from the library of the Victorian artist, George Cruikshank, with his pencil sketches. Apparently Cruikshank used costume 
books such as this, engraved by Hollar, to study period dress for characters in illustrations, such as his Falstaff plates (see above, no.8)

\section{CASES 6 and 7}

Ghosts, Fairies, Elves, Visions, Dreams, Nightmares.

Artists or editions represented in these cases are from the $18^{\text {th }}, 19^{\text {th }}$ and early $20^{\text {th }}$ centuries.

CASE 6, the large case in the corner of the room near CASE 5, begins with two small books in the center. These two illustrations represent Richard III on the battlefield, the night before his final struggle. He is haunted by the ghosts of the many people he has murdered.

From these two small books, proceed to the largest book in the case, in the corner to your upper left. Here is Shakespeare's most famous ghost - Hamlet's murdered father appearing on the platform of the castle walls, in a lithograph by the great French artist, Eugène Delacroix. The platform scene in Hamlet is a favorite subject for artists who often quote each other. Hamlet in a dynamic pose bending forward, with one arm outstretched toward the ghost, can be seen in several variations that echo both theatrical and artistic traditions. Delacroix surely was familiar with Henry Fuseli's interpretation of this scene (see a copy of this engraving in the adjacent wall case, CASE 7).

The Hamlets of two other artists, Robert

Dudley and William Blake, are also

represented in CASE 7. But featured prominently on the left in CASE 7 are two original prints from paintings in the Boydell Gallery - two very differen images of Puck. Sir Joshua Reynolds, founder of the Royal Academy of Art in England and conservator of traditions inherited frc painted a beautiful but ing hely traditional cherubic Puck. Fuseli had a very different vision of Shakespeare's Puck.

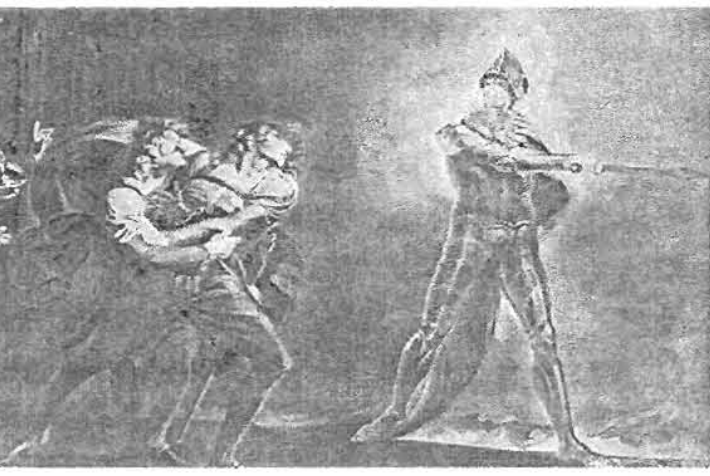

The $19^{\text {th }}$ century is clearly the great period of Shakespearean illustration. The Victorian in particular were lovers of Shakespeare's fairies, elves and gothic creations. Plays such as A Midsummer Night's Dream and The Tempest provided compelling supernatural material for their artists. Several examples are represented in CASES 6 and 7 , including the fanciful illustrations of Kenny Meadows and J. Mohr Smith in CASE 6 and of Sir John Everet Millais and Sir Joseph Noël Paton in CASE 7.
In this exhibit there is space for only a very few examples of the many foreign illustrations of Shakespeare in the University Library's Special Collections. French and Italian influence tended to dominate $17^{\text {th }}$ and $18^{\text {th }}$ century engraving in England, but in the early $19^{\text {th }}$ century German influence was becoming more pronounced. The multilingual edition of The Tempest, with outline wllustrations by Henry Courney. The multilingual edition of The Tempest, with outline illustrations by Henry Courtney Selous, perhaps reflects this German influence.

\section{CASE 6}

1 WILLIAM SHAKESPEARE, 1564-1616

\section{Richard III}

The Works of Shakespeare, in eight volumes, v. 5

Illustration after François Boitard, by Pierre Fourdrinier, fl. 1720-1760

London, for $J$. Tonson and the rest of the proprietors, 1735

Many of the engravings for the 1709 first illustrated edition of Shakespeare suggest scenic elements of an actual Restoration stage production. This 1735 edition, with plates pirated from the original 1709 edition, shows Richard confronted by the ghosts of his past. On the left a ghost seems to be rising from the floor. Perhaps this is the designer's rather crude representation of an actor rising through a trap door in the stage floor.

\section{WILLIAM SHAKESPEARE, 1564-1616}

\section{Richard III}

The Plays of William Shakespeare, in twelve volumes, v. 8

Illustration by John Thurston, 1774-1822

London, for E. Harding, 1800

This illustration of the same scene was engraved almost a century after the original lustrated edition in 1709 and a decade after the first exhibition of the Boydell Gillery While the design reflects $18^{\text {th }}$-century painterly traditions, the artist may have be (see Case

3 WILLIAM SHAKESPEARE, 1564-1616

Hamlet, Prinz von Daenemark

Illustrated by Eugène Delacroix, 1798-1863

Leipzig, Inselverlag, 1913

French artists were also influenced by a growing appreciation of the English Bard. Delacroix created his Hamlet lithographs in 1835, and the first published edition was 
issued in Paris in 1843 and reprinted in 1863. This rare copy of a later German reprint of the Paris edition is one of only 100 copies.

\section{WILLIAM SHAKESPEARE, 1564-1616} Scenes from "The Winter's Tale"

Illuminators Owen Jones, 1809-1874, Henry Warren, 1794-1879

On stone by A. Warren

London, Day and Son, [1865]

The Victorian designer, Owen Jones, was among the early English book illustrators experimenting with color lithography. This plate depicting Hermione's miraculous "resurrection" from stone, reflects Jones' highly decorative style, with Arabic and Egyptian influences.

\section{WILLIAM SHAKESPEARE, 1564-1616}

A Midsommer Nights Dreame

Illustrated by John Moyr Smith. 1839-1912

London, Bernard Quaritch, 1892

J. Mohr Smith is one of many Victorian artists fascinated with the world of the supernatural. A Midsummer Night's Dream and The Tempest not surprisingly are featured plays for illustrations of the world of fairies, magic and dreams.

6 WILLIAM SHAKESPEARE, 1564-1616

Outlines to Shakespeare's "Tempest"

Series of twelve plates by Henry Courtney Selous, 1803-1890

With the text in English, German, French, and Italian

London, A. Schloss, [1836]

7 WILLIAM SHAKESPEARE, $1564-1616$

A Midsummer Night's Dream

Illustrated by William Heath Robinson, 1872-1944

London, Constable \& Co., 1914

8 WILLIAM SHAKESPEARE, 1564-1616

Etchings to the Illustrated Shakspere

Designed by Kenny Meadows, 1790-1874

London, Wm. S. Orr and Co., [1845]

9 WILLIAM SHAKESPEARE, 1564-1616

Ein Sommernachtstraum

Illustrated by Julius Höppner, 1839-

Munich, Theo. Stroefer's Kunstverlag, [1888]

\section{CASE 7 left panel}

$1 \quad$ Engraving (original print), after a painting

By Sir Joshua Reynolds, 1723-1792

Puck, A Midsummer Night's Dream

Printed for J. \& J. Boydell

London, 1799

2 Engraving (original print), after a painting By Henry Fuseli, 1741-1825

Puck, A Midsummer Night's Dream

Printed for J. \& J. Boydell

London, 1802

3 Engraving, after a painting by Thomas Stothard, 1755-1834 Titania's Awakening, A Midsummer Night's Dream

Printed for James Heath, 1757-1834

London, 1802

$4 \quad$ Painting by Henry Fuseli, 1741-1825

Titania's Awakening, 1785/89

A Midsummer Night's Dream

Kunstmuseum, Winterthu

$5 \quad$ Painting by Sir John Everett Millais, 1829-1896

Ferdinand Lured by Ariel, 1849/50

The Tempest

Makins Collection, England

$6 \quad$ Painting by Sir Joseph Noel Paton, 1821-190

Quarrel of Oberon and Titania, 1849

A Midsummer Night's Dream

National Gallery of Scotland, Edinburgh

\section{CASE 7 right panel}

1 Engraving, after a painting by Henry Fuseli, 1741-1825

Hamlet and His Father's Ghost, Hamlet

From The Boydell Gallery

London, 1805

2 Watercolor by William Blake, 1757-1827

Hamlet and His Father's Ghost, 1806

Hamlet

British Museum, London

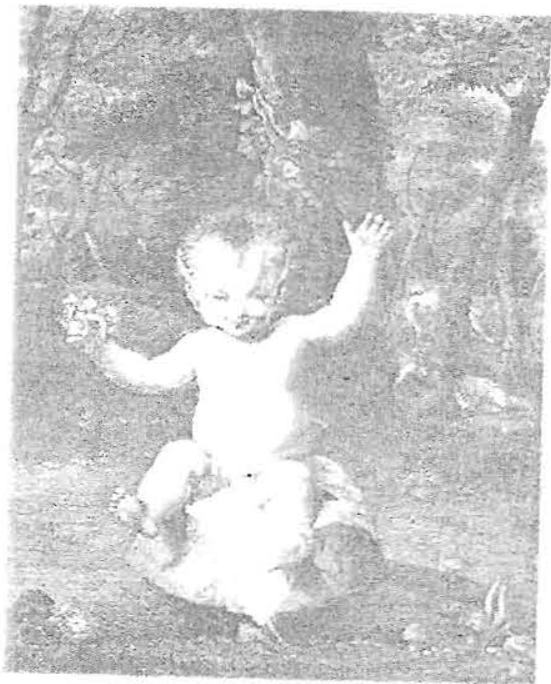


3 Watercolor by William Blake, 1757-1827

Brutus and Caesar's Ghost, 1806

Julius Caesar

British Museum, London

$4 \quad$ Watercolor by William Blake, 1757-1827

Richard III and the Ghosts, 1806

Richard III

British Museum, London

$5 \quad$ Watercolor by William Blake, 1757-1827

Vision of Queen Katherine, 1825

Henry VIII

National Gallery of Art, Washington, DC

$6 \quad$ Etching by Robert Dudley, fl. 1858-1893

Hamlet and His Father's Ghost, Hamlet

From The Library Shakespeare v.7

London, 1875

\section{CASES 8,9 and 10}

Actors, Interpretations of the Role, and Illustrations of Specific Characters.

Most of the books and images in these cases are from the $18^{\text {th }}$ and $19^{\text {th }}$ centuries, the great period of the actor/manager in the English theatre.

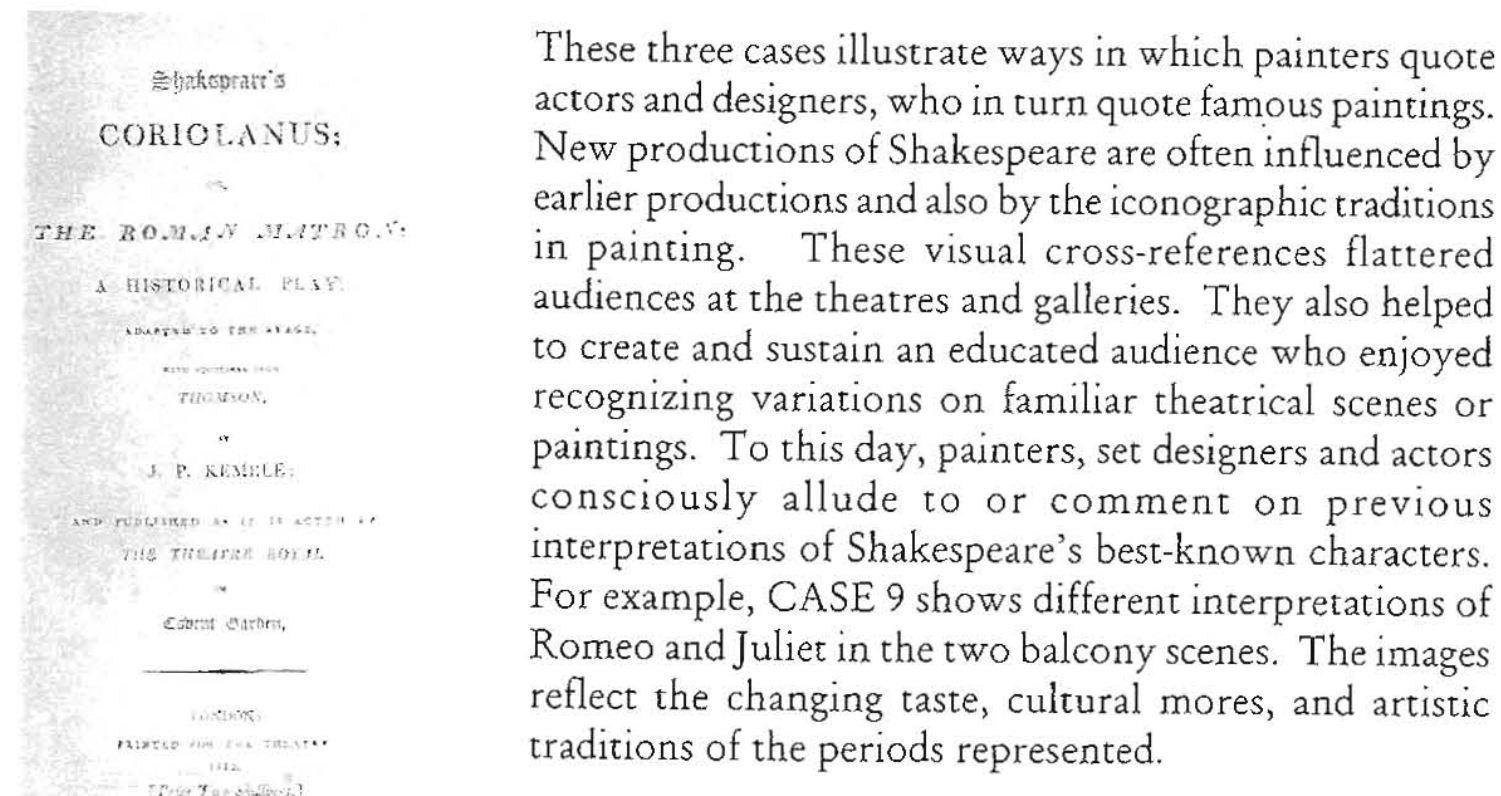

\section{CASE 8}

1 WILLIAM WINTER, 1836-1917

James Hackett, 1800-1871, in his famous role of Falstaff

Shadows of the Stage, second series

Boston, Joseph Knight Company, 1893

Compare this portrait of Hackett as Falstaff in The Merry Wives of Windsor with earlier images of Falstaff in CASES 4 and 5.

2 JOHN PHILIP KEMBLE, 1757-1823

Memoirs of John Philip Kemble

Extra-illustrated; frontispiece by $\mathrm{H}$. Melvill

London, for J.B. Wood, 1817

This engraving depicts John Philip Kemble as Coriolanus, perhaps his most famous role.

3 WILLIAM SHAKESPEARE, 1564-1616

The Works of William Shakespeare, v. 8

The Garrick Shakespeare

London, William Heinemann, 1905

The frontispiece to this volume is from one of many paintings of John Philip Kemble as Coriolanus. Kemble's proud posture in Roman dress has been quoted many times by artists and actors alike.

4 THEATRE ROYAL, DRURY LANE

[Playbill for] King Lear

Starring Edmund Kean, 1787-1833

London, June 3, 1820

5 FREDERICK WILLIAM HAWKINS, 1849-1900

The Life of Edmund Kean

London, Tinsley Brothers, 1869

Hand-colored illustration of Edmund Kean as King Lear. See the playbill for Kean's Lea above (no.4).

6 MACREADY, WILIAM CHARLES, 1793-1873

Mr. Macready as King Lear (V.3)

In: Dramatic Album, Mayall, etc., etc.

A collection of steel engravings for Tallis's drawing room table book of theatrical portraits from original drawings and daguerreotypes by Beard, Mayall, etc., etc. [London, New

York, J. Tallis \& Co., 18-] 
A similar portfolio of actors in famous roles in the University Library's Special Collections was previously owned by the influential $19^{\text {th }}$-century English actor and theatre manager, Sir Henry Irving. Irving in turn has been engraved in his famous role of Hamlet. See

CASE 10.

7 G. W. THORNE

[Copy of a photograph of] Edwin Booth as Hamlet

New York, J. Gurney, 1870

As is obvious from the printed signatures and the photographer's backdrop, this is a studio portrait of Edwin Booth as Hamlet. Nevertheless, for this studio "sitting," Booth apparently wore his famous costume and brought with him some of his props, including his sword.

EDWARD ROBINS, 1862-1943

\section{Twelve Great Actors}

Engraving from a photograph of Edwin Booth as Hamlet

New York and London, G.P. Putnam's Sons, 1900

This engraving is based on the studio pose shown in no.7 above.

9 WILLIAM WINTER, 1836-1917

Mr. Edwin Booth in His Various Dramatic Characters

Portraits by William John Hennessy, 1839-1917

Engravings by William James Linton, 1812-1897

Boston, Jas. R. Osgood \& Co., 1872

One of many artists' renditions of Booth as Hamlet. Here, with the same costume, Booth is shown in the graveyard scene.

10 PERCY HETHERINGTON FITZGERALD, 1834-1925 The Kembles, an Account of the Kemble Family, v.1 London, Tinsley Brothers, [1871]

This engraving shows the famous sister of John Philip Kemble, Sarah Siddons (1755-1831), as Lady Macbeth. Although this scene is apparently Lady Macbeth sleepwalking (note the lamp in her hand), the dramatic posture of Siddons in the role suggests the famous painting and engraving by Henry Fuseli of the earlier actress Hannah Pritchard (1711-1768) playing Lady Macbeth opposite David Garrick's Macbeth. See CASE 10.
11 LYCEUM THEATRE

Souvenir of "Macbeth"

Produced at the Lyceum Theatre, 29th December, 1888

By Sir Henry Irving, 1838-1905

London, Cassell \& Company, [1888]

Irving was featured with Ellen Terry in this famous production of Macbeth, directed by Irving.

\section{CHARLES HIATT' 1869}

Ellen Terry and Her Impersonations

From a photograph of Ellen Terry as Lady Macbeth

London, George Bell, 1898

This photograph shows Terry in the sleepwalking scene, raising the lamp above he head. Although this image is from a studio photograph, not a stage-production photograph, Terry is probably quoting her own interpretation of the scene on the stage.

13 WILLIAM SHAKESPEARE, 1564-1616

The Works of William Shakespeare, v.13

From a painting by John Singer Sargent, 1856-1925

The Garrick Shakespeare

London, William Heinemann, 1905

Art historians have noted that it was Sargent's decision to have Ellen Terry as Lady Macbeth raise the crown above her head. Apparently Terry did not make this gesture 政 Sargent may have been quoting Terry's ironic use of the lifted lamp in the sleepwalking scene (see above, no.12)

\section{CASE 9}

1 WILLIAM SHAKESPEARE, 1564-1616

\section{Romeo and Juliet}

The Plays of William Shakespeare, v. 8

Illustration by Edward Francis Burney, 1760-1848

London, for Bellamy and Robarts, 1791

This engraving has Romeo in the traditional dramatic posture of an early $18^{\text {th }}$-century actor, in period dress with a sword at his side, pointing melodramatically to an unseen moon. Juliet is high above on a distant balcony, also in a traditiona pose.

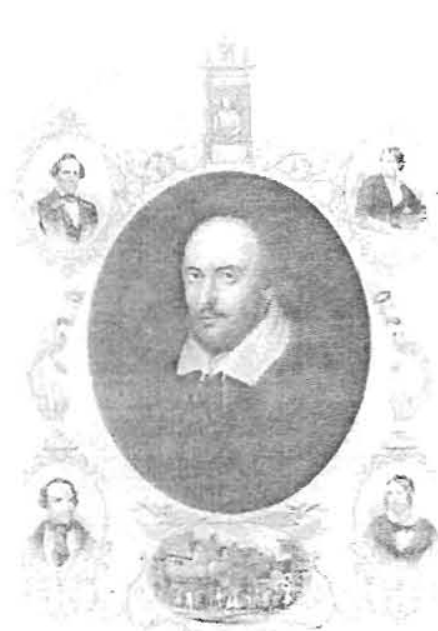


WILIAM SHAKESPEARE, 1564-1616

Romeo and Juliet

The Plays of William Shakespeare, in twelve volumes, v.1

Illustration by John Thurston, 1774-1822

London, for E. Harding, 1800

In this "post-Boydell" illustration of the same balcony scene from Act II as depicted in the Bellamy illustration above (no.1), Romeo is in the more modest dress of a middleclass gentleman. He is shyly clutching his hat behind his back and has wisely left his sword at home. The balcony is no longer set high above, but seems a more realistic and intimate rendition of a contemporary $18^{\text {th }}$-century London home. A hazy romantic moon is visible in the background, making the scene quite appealing to contemporaries who preferred a sentimental interpretation of the tragedy.

3 WILLIAM SHAKESPEARE, 1564-1616

Romeo and Juliet

Illustrated by Frank Bindley

London, Belfast, New York, Marcus Ward \& Co., [189-?]

CHARLES LAMB, 1775-1834, MARY LAMB, 1764-1847

The Tale of Romeo and Juliet

Tales from Shakespeare, v. 2

Illustrated by Harold Copping, d. 1932

London, Paris, New York, Raphael Tuck \& Sons, 190

Here is a depiction of the second balcony scene, labeled on the protective tissue "Romeo leaving his dear wife." Despite the chaste title, the lovers have obviously just gotten out of bed.

5 WILLIAM SHAKESPEARE, 1564-1616

Romeo and Juliet

Illustrated by Ludovic Marchetti, Lucius Rossi, Oreste Cortazzo

London, Paris, New York, Raphael Tuck \& Sons, [189-]

In this illustration the lovers are separated by the book-designer's two-page spread. But they will soon be united, for Romeo's sword has now morphed into a very phallic dagger.

CHARLOTTE CUSHMAN, 1816-1876

[Charlotte and Susan Cushman as Romeo and Juliet]

In: Dramatic Album, Mayall, etc., etc.

A collection of steel engravings for Tallis's drawing room table book of theatrical portraits from original drawings and daguerreotypes by Beard, Mayall, etc., etc. [London, New York, J. Tallis \& Co., 18-]
This engraving represents the actress Charlotte Cushman in probably her most famous role as Romeo, with her sister Susan as Juliet, in the second balcony scene. The Cushman are standing in chaste studio poses, as originally caught in an early sketch or daguerreotype.

7 WILLIAM SHAKESPEARE, 1564-1616

The Complete Works of Shakespeare, v.2

Philadelphia, William T. Amies, 1878

For the engraved frontispiece to the second volume of this 1878 collected edition of Shakespeare, the publisher has chosen the same balcony scene in which Charlotte Cushman as Romeo is leaving his Juliet's bedroom. But in this design Cushman has been transformed into a Romeo with a short tunic revealing very feminine thighs and lace pantaloons.

\section{CASE 10 left panel}

$1 \quad$ Painting by Charles A. Buchel of

Sir Herbert Beerbohm Tree, 1853-1917 as

Malvolio in Beerbohm Tree's Twelfth Night

From Souvenir ... [of the Production]

London, 1901

2 Beerbohm Tree as Malvolio in silhouette

Detail from the front cover of Souvenir ... [of the Production]

Cover design by Charles A. Buche

London, 1901

3 Souvenir for Twelfth Night, produced by

Harley Granville-Barker, 1877-1946

Front cover (original) of The Play Pictorial, (v.21, no.126)

London, 1913

$4 \quad$ Photograph of a scene in Olivia's garden, from the

Harley Granville-Barker production of

Trwelfth Night, (I.5)

With Lillah McCarthy as Viola and Henry Ainley as Malvolio

From the unpublished Granville-Barker promptbook

[London, 1912]

5 Photograph of a scene with Titania and Oberon

From the Harley Granville-Barker production of

A Midsummer Night's Dream (II, i)

From the unpublished Granville-Barker promptbook

[London, 1914?] 
6 Property plot for the Harley Granville-Barker production of

A Midsummer Night's Dream

From the unpublished Granville-Barker promptbook

With the title leaf from 1912 Heineman edition bound in

[London, 1914?]

7 Detail of a photogravure frontispiece

From the 1912 Heineman edition of Shakespeare's plays

Illustrating Oberon and Titania in

Sir Herbert Beerbohm Tree's production of

A Midsummer Night's Dream

This frontispiece is bound into the Granville-Barker promptbook

[London, 1914?]

\section{CASE 10 right panel}

1 Etching (original print) by "MSR" (?)of

William Charles Macready in Othello

from Dramatic Recollections ...

"Drawn and etched from memory by MSR"

London, 1839

The artist "MSR" has not been identified but apparently was quite familiar with Macready on the stage.

2 Engraving (original print), after a painting by

William Hogarth, 1697-1764

David Garrick in Richard III

From 96 Portraits of Eminent Actors...

London, New York, 18-?

This famous interpretation of Richard III by the $18^{\text {th }}$-century actor David Garrick (17171779) has been the subject of a number of paintings, including this design by William Hogarth. Hogarth is quoting Garrick's famous posturing as Richard III in his tent on the battlefield, as he confronts the ghosts of his past, the night before his death.

3 Painting by Henry Fuseli, $1741-1825$

David Garrick and Mrs. Pritchard in Macbeth, 1812

Tate Gallery, London

$4 \quad$ Engraving, after a painting by

Henry Fuseli, 1741-1825

David Garrick and Mrs. Pritchard in Macbeth

Printed for James Heath, 1757-1834

London, 1804
5 Engraving of Sarah Siddons, $1755-183$

Sleepwalking scene in Macbeth

From $A$ Century of Famous Actresses

London, 1913

This quiet interpretation of Sarah Siddons as Lady Macbeth in the sleepwalking scene contrasts with the dramatic pose of Siddons as Lady Macbeth depicted in CASE 8 no. 10 .

6 Engraving of Sir Henry Irving, 1838-1905

In the title role of Hamlet

From 96 Portraits of Eminent Actors...

London, New York, 18-?

Front cover to Henry Irving, Ellen Terry:

A Book of Portraits by

Edward Gordon Craig, 1872-1966

Chicago, c1899

Ellen Terry was the mother of Edward Gordon Craig. the influential modernist set designer. For an example from this Book of Portraits, see Craig's idealized portrait of his mother as Ophelia, reproduced in CASE 12.

$8 \quad$ Lithograph by Edward Gordon Craig, 1872-1966

Sleepwalking scene in Macbeth

From The Players' Shakespeare, v.21

London, 1923

This sketch by Craig is apparently based on Terry in the role of Lady Macbeth.

$9 \quad$ Painting by John Singer Sargent, $1856-1925$

Ellen Terry as Lady Macbeth, 1889

Tate Gallery, London

See also CASE 8.

\section{CASES 11, 12 and part of 13}

Illustrating the "Other" - Orientalism, Dark and Alien Figures, Mad Women ...

A fascinating way to study changing interpretations of Shakespeare is to take the hundreds of different illustrations of some of his most famous and controversial characters and investigate how their interpretations reflect the changing mores and cultural preferences of the times. The images in these three cases display numerous 
examples of Caliban, Ophelia, Cleopatra, and Othello. The canonical Shakespeare gave Victorian illustrators an opportunity to present surprisingly sexualized characters and scenes.

\section{CASE 11}

1 WILLIAM SHAKESPEARE, 1564-1616
Othello
The Plays of William Shakespeare, in twelve volumes, v.12
Illustration by John Thurston, 1774-1822

London, for E. Harding, 1800

Othello in this image seems quite alien and threatening, with the large phallic candle and the vulnerable, sleeping Desdemona, her breasts visible through her diaphanous gown.

2 CHARLES LAMB, 1775-1834, MARY LAMB, 1764-1847

Tales from Shakespear, Designed for the Use of Young Persons

The fourth edition, v.2

Illustrations by William Mulready, 1786-1863

London, for M. J. Godwin and Co., 1822

In this set of tales for children the illustrator has drawn an evil-looking Othello stalking Desdemona with a drawn dagger.

3 CHARLES LAMB, 1775-1834, MARY LAMB, 1764-1847

Tales from Shakespeare, Stories for the Children

Retold by Edith Robarts

London, Ward, Lock \& Co., New York, the Platt \& Peck Co., 1911

The cover to this edition of Lamb's Tales from Shakespeare depicts a frail and distracted Ophelia.

WILLIAM SHAKESPEARE, 1564-1616 Othello

The Comedies, Histories, E Tragedies of

William Shakespeare, v.11

Designed by Bruce Rogers, 1870-1957

Illustrations by Robert Gibbings, 1889-1958

New York, Limited Editions Club, 1939-1940

Othello in this series of woodcuts is drawn in heroic and noble dimensions.
5 WILLIAM SHAKESPEARE, 1564-1616

The Works of Mr. William Shakespear, in ten volumes, v.7

Illustration, after François Boitard by Pierre Fourdrinier, fl. 1720-1760

London, for J. and J. Knapton, 1728

6 CHARLES HEATH, 1785-1848

The Heroines of Shakespeare, ... from Drawings by Eminent Artists

Illustration by John William Wright, 1802-1848

London, David Bogue, 1848

Here Cleopatra is seen as an alien oriental, with a jeweled snake bracelet around her arm; but she is also sentimentalized with a tear.

\section{GALÉRIE DES FEMMES DE SHAKESPEARE}

Text by George Sand, 1804-1876

Illustration by Kenny Meadows, 1790-1874

Paris, J.-B. Fellens et L.-P. Dufour, [184-?]

Kenny Meadows' image of Cleopatra is of a large-hipped Victorian woman in vaguely oriental dress. But the sympathetic text by George Sand reflects Sand's personal philosophy that lovers should not be bound by the conventions of culture and class. Sand's essay is from her "Les Femmes de Shakespeare," originally published in 1837

WILLIAM SHAKESPEARE, 1564-1616

\section{Antony and Cleopatra}

The Comedies, Histories, \& Tragedies of William Shakespeare, v.19

Designed by Bruce Rogers, 1870-1957

Illustrations by Enric Cristòfol Ricart i Nin, 1893-1960

New York, Limited Editions Club, 1939-1940

This delightful illustration shows a sensuous Cleopatra languishing on her barge and surrounded by exotic and voluptuous sea nymphs. 


\section{CASE 12 left panel}

1 Lithograph, after an etching by

John Hamilton Mortimer, 1741-1779

Caliban, The Tempest

From Mortimer's Illustrations of Shakspeare

London, 1838

Although he has claws, Caliban is sympatherically portrayed by Mortimer.

2 Wood engraving by Gustave Doré, 1832-1883

Caliban, from The Tempest (II.2)

New York, 1861

Dorés Caliban is drawn with African features, bent over a snake-infested wood pile.

3 Engraving, after a painting by

Thomas Stothard, 1755-1834

Caliban, The Tempest

From The Plays of William Shakespeare

London, 1800

This relatively early illustration shows a barbaric Caliban with fangs, claws, and body hair, crouching in a cave in the company of snakes.

$4 \quad$ Illustration from a painting by F. K. Rogers

Caliban, The Tempest

From The Ben Greet Shakespeare ...

Garden City, NY, 1912

This design is for a children's text about the theatre. Here a dangerous-looking Caliban

dwells in a hellish setting, tormented by devil-like creatures.

$5 \quad$ Illustration from a painting by Paul Woodroffe

Caliban, The Tempest

London, 1908

Here is a more sympathetic Caliban, a burdened old man with pointed ears. Ariel also seems more benign, teasing rather than tormenting.
6 Illustration from a hand-colored line drawing by

Arthur Rackham, 1867-1939

Caliban, The Tempest

From Charles and Mary Lamb's Tales from Shakespeare

London, New York, 1909

Rackham's delightful Caliban is a totally alien creature in a playful world with Ariel sporting butterfly wings.

$7 \quad$ Engraving, after a design by

Edward Edwards, 1738-1806

Caliban, The Tempest, 1773

From Bell's Edition of Shakespeare's Plays

London, 1774

Caliban in this image is a hungry savage fed by European explorers.

8 Wood engraving, after a design by

Robert Anning Bell, 1863-1933

Caliban, The Tempest

From The Tempest ...

London, 1901

This simian figure seems more sympathetic than most semi-human Calibans. $\mathrm{He}$ crouches like a pet monkey within a protective frame of attending mermaids.

9 Wood engraving from a pen drawing by

Walter Crane, 1845-1915

Caliban, The Tempest

From Eight Illustrations to The Tempest..

London, 1893

\section{CASE 12 right panel}

1. Etching by Richard Redgrave, 1804-1888

"The Song of Poor Barbara," Othello (IV.3)

From Songs and Ballads of Shakespeare

The Etching Club

London, 1852

This image of Poor Barbara from a song in Othello could easily be confused with typical images of Ophelia wearing a garland of flowers. 
2 Lithograph, after an etching by

John Hamilton Mortimer, 1741-1779

Ophelia, Hamlet

From Mortimer's Illustrations of Shakspeare

London, 1838

Ophelia is sympathetically drawn, but her wide eyes tells the experienced reader of illustrations that she is mad.

3 Illustration, after a painting by

Sir John Everett Millais, 1829-1896

Ophelia, Hamlet

From The Complete Works of William Shakespeare

London, Glasgow, 1910

Millais' famous painting, reproduced as a frontispiece in this edition of Shakespeare,

has been quoted many times in stage productions, paintings and photographs.

$4 \quad$ Painting by Arthur Hughes, 1830-1915

Ophelia, 1852

City Art Gallery, Manchester, England

Hughes, a contemporary of Millais, also imagines Ophelia as frail and vulnerable

$5 \quad$ Woodcut by Edward Gordon Craig, 1872-1966

Ellen Terry as Ophelia

From Craig's Henry Irving, Ellen Terry: a Book of Portraits

Chicago, c1899 (see also CASE 10)

This idealized portrait of Craig's mother as Ophelia seems far from the role Ellen

Terry actually created. Compare this with her Lady Macbeth.

CASE 13 upper left corner (additional examples from Othello and Antony and Cleopatra)

1 Engraving attributed to François Boitard

Othello and Desdemona, Otbello

From The Works of Mr. Shakespear...

London, 1709

2 Engraving, after a design by

Henry Fuseli, 1741-1825

Othello and Desdemona

From The Plays of William Shakspeare

London, 1805
3 Engraving, after a painting by

John William Waterhouse, 1849-1917

Cleopatra, Antony and Cleopatra

From Graphic Gallery of Shakespeare's Heroines

London, 1888

$4 \quad$ Engraving, after a painting by

Sir Francis Bernard Dicksee, 1853-1928

Antony and Cleopatra

From Shakespearean Scenes and Characters

London, 1886

$5 \quad$ Woodcut by Harry G. Spanner

Othello, 1933

From a greeting card for the Saturn Press

Swan's Island, Maine, 1998

\section{CASE 13}

Illustrating Shakespeare's Poetry - the Sonnets, "Who Is Silvia?" and "The Seven Ages of Man"

CASE 13 lower left corner

"Who is Silvia?"

1 Etching (original print) by ames Clarke Hook, 1819-1907

"Who is Silvia? What is she? ..." Two Gentlemen of Verona (IV.2)

From Songs and Ballads of Shakespeare

The Etching Club

London, 1852

2 Wood engraving by Joseph Kenny Meadows, 1790-1874

Silvia, Two Gentlemen of Verona

From Characteristics of Women by

Mrs. Anna Jameson, 1794-1860

New York, London, 1848

3 Engraving, after a painting by

Charles Edward Perugini, 1839-1918

Silvia, Two Gentlemen of Verond

From Graphic Gallery of Shakespeare's Heroines

London, 1888 
CASE 13 right panel Two sonnets from Shakespeare, and "the whining school boy"

1 Engraving (original print) by Peter Lipman-Wulf, 1905"Like as the waves...," Sonnet 60

From Lipman-Wulf's Images to Shakespeare's Sonnets Garden City, N.Y., 1964

$2 \quad$ Illustration by Sir John Gilbert, 1817-1897 "As a decrepit father takes delight ...," Sonnet 37 From The Library Shakespeare v.9

London, 1875

3 Hand-colored engraving, after a drawing by Thomas Stothard, 1755-1834

School Boy, As You Like It (II.7)

From Shakspeare Seven Ages of Man Illustrated

London, 1799

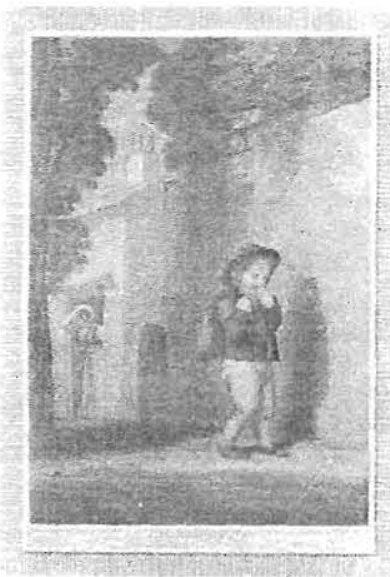

This image is taken from Jaques' famous lines describing "the seven ages of man" in $A s$ You Like It. The accompanying text comments on the relationship between the illustration and Shakespeare's verse.

\section{CASES 14 and 15}

20th-Century Artists - a Few Examples

\section{CASE 14}

1 WILLIAM SHAKESPEARE, 1564-1616

Macbeth

Illustrated by Salvador Dali, 1904-1989

Garden City, NY, Doubleday \& Co., 1946

2 LUCHINO VISCONTI, 1906-1976

William Shakespeare, Come Vi Piace (As You Like It)

Scenery and costumes by Salvador Dali, 1904-1989

Rome, C. Bestetti, 1948
3 WILLIAM SHAKESPEARE, 1564-1616

The Tragedy of Hamlet, Prince of Denmark

Designed and illustrated by Eric Gill, 1882-1940

London], The Limited Editions Club, 1933

4 WIULTAM SHAKESPEARE, 1564-1616

The Tragedie of King Lear

Illustrated by Claire Van Vliet

Bangor [Maine], Theodore Press 1986

5 JEAN COCTEAU, 1889-1963

Oedipe-Roi, Roméo et Juliette

Scenery and costumes by Jean Hugo, 1894-

Paris, Plon, [1928]

6 WILLIAM SHAKESPEARE, 1564-1616

Shakespeare's Macbeth

The Players' Shakespeare, v.2

Introduction by Harley Granville-Barker, 1877-1946

Illustrated by Charles S. Ricketts, 1866-1931

London, Ernest Benn, 1923-1927 (Stratford-upon-Avon,

Shakespeare Head Press)

\section{CASE 15 left pane}

$1 \quad$ Mixed media illustration by Jim Dine, 1935

Puck, 1966

From a series of 26 costume and scene designs

For a production of $A$ Midsummer Night's Dream

at the Theatre de Lys, New York

Museum of Modern Art, New York

$2 \quad$ Painting by Jules Olitski, 1922

Anthony [sic] and Cleopatra, 1989

André Emmerich Gallery, New York

3 Woodcut by Paul Nash, 1899-1946

From A Midsommer Nights Dream

The Players' Shakespeare, v. 4

Introduced by Harley Granville-Barker, 1877-1946

Printed at the Shakespeare Head Press

London, 1924

See CASE 14, no.6 for another example of illustrations for The Players'Shakespeare. 
$4 \quad$ Lithograph from a painting by Molnár C. Pál, 1894 -

From Coriolanus

The Plays of William Shakespeare...

The Limited Editions Club

Designed by Bruce Rogers, 1870-1957

New York, 1939-1940

See CASE 11, no. 8 for another example of illustrations for the Bruce Rogers' Shakespeare.

\section{CASE 15 right panel}

1 Etching (original print) by Leonard Baskin, 1922-2000

"Roman Caesar, " representing corrupt imperial power

From the extra suite of prints issued with

Titus Andronicus, printed by hand at

The Gehenna Press

Northampton, Mass., 1973

2 Wood engraving by Leonard Baskin, 1922-2000

Othello and Desdemona

From Othello, printed by hand at

The Gehenna Press

Northampton, Mass., 1973

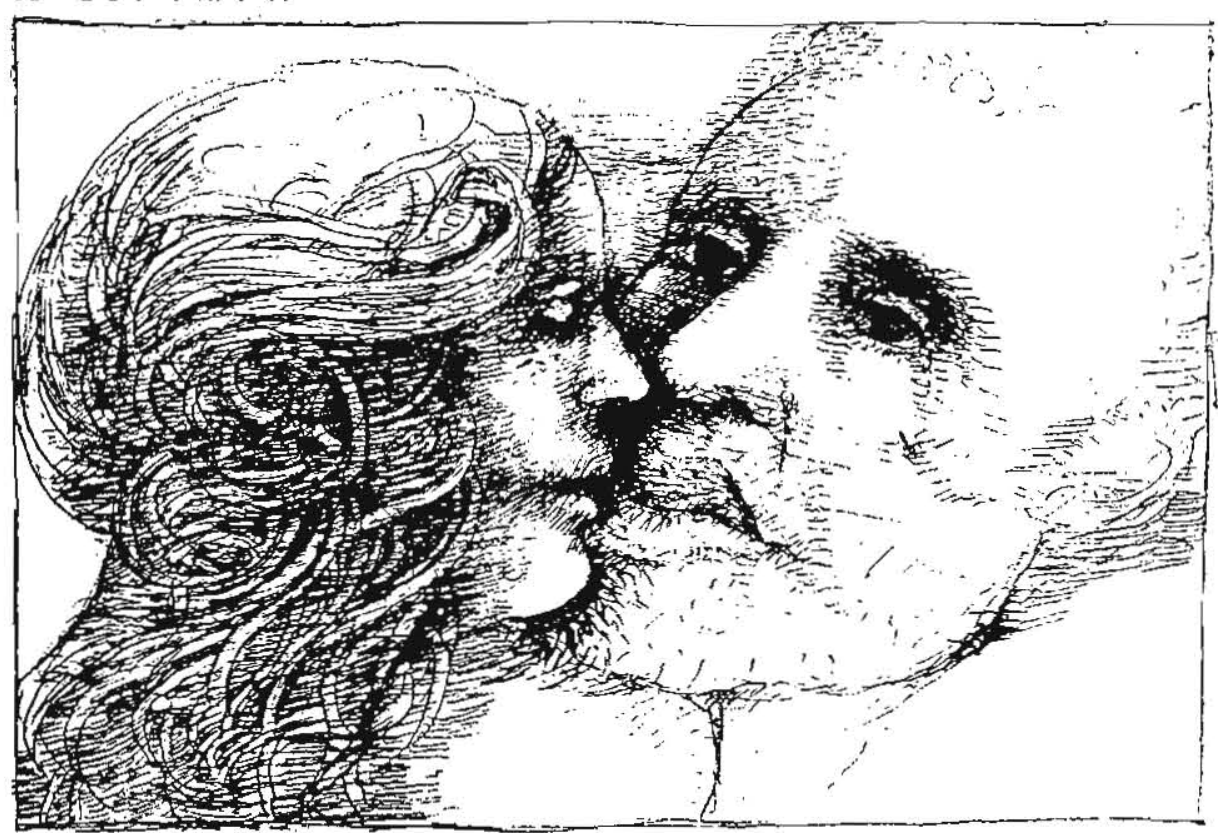

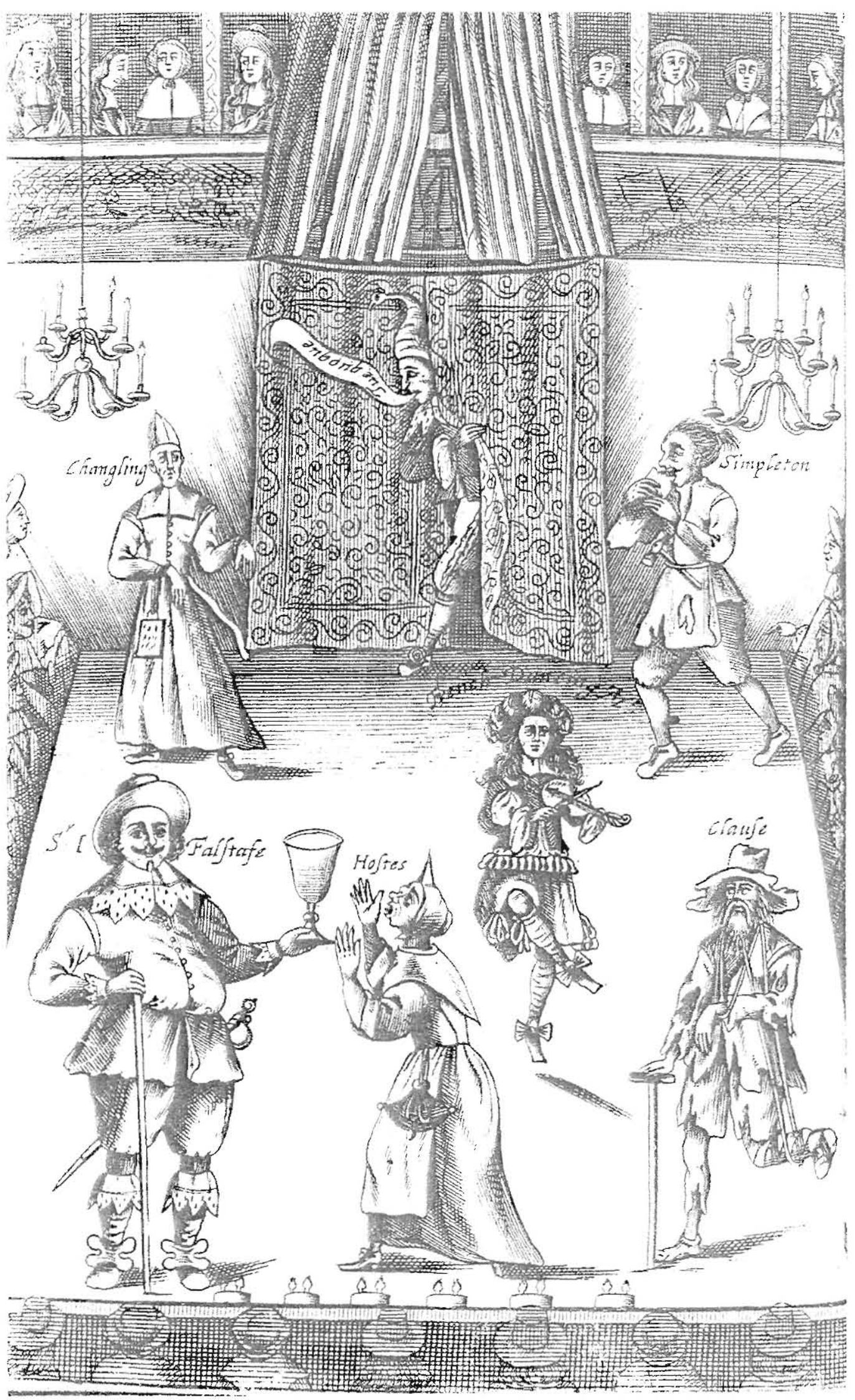




\section{IPCOMING EXHIIBLT:}

"Suave Mechanicals: Early to Modern Binding Styles."

Guest Curator: Julia Miller

Exhibit Dates: March 24 - July 26, 2003

Opening Lecture:

"Beauty, Craft, Function: A History of Book Structure"

by Pamela Spitzmueller

Needham Conservator, Harvard University

April 3, 2003 af $8: 00 \mathrm{pm}$

in the

Special Collections Library

Tth Floor, Harlan Hatcher Graduate Library

University of Michigan

Ann Arbor MI 48109-1205

(734) 764-9377

special.collections@umich.edu

www.lib.umich.edu/spec-coll/

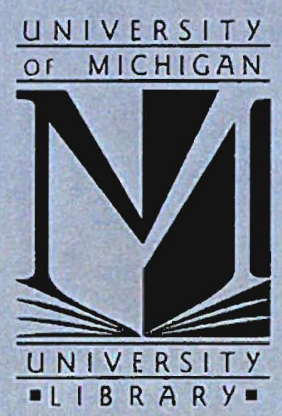

